\title{
Physicochemical and Antioxidant Properties of Gelatin and Gelatin Hydrolysates Obtained from Extrusion-Pretreated Fish (Oreochromis sp.) Scales
}

\author{
Wei-Cheng Shiao ${ }^{1,+}$, Tien-Chiu Wu ${ }^{2,+}$, Chia-Hung Kuo ${ }^{3}{ }^{-}$, Yung-Hsiang Tsai ${ }^{3}$, Mei-Ling Tsai ${ }^{3}$, \\ Yong-Han Hong ${ }^{4, *}$ and Chun-Yung Huang ${ }^{3, *}$ (D)
}

1 Division of Gastroenterology (General Medicine), Department of Internal Medicine, Yuan's General Hospital, No.162, Cheng Kung 1st Rd., Lingya District, Kaohsiung 80249, Taiwan; cheng_2034@yahoo.com.tw

2 Division of Hematology and Oncology, Department of Internal Medicine, Kaohsiung Medical University Hospital, Kaohsiung Medical University, Kaohsiung 80756, Taiwan; 960552@ms.kmuh.org.tw

3 Department of Seafood Science, National Kaohsiung University of Science and Technology, No. 142, Haijhuan Rd., Nanzih District, Kaohsiung 81157, Taiwan; kuoch@nkust.edu.tw (C.-H.K.); yht@nkust.edu.tw (Y.-H.T.); mltsai@nkust.edu.tw (M.-L.T.)

4 Department of Nutrition, I-Shou University (Yanchao Campus), No.8, Yida Rd., Jiaosu Village, Yanchao District, Kaohsiung 82445, Taiwan

* Correspondence: yonghan@isu.edu.tw (Y.-H.H.); cyhuang@nkust.edu.tw (C.-Y.H.); Tel.: +886-7-6151100 (ext. 7914) (Y.-H.H.); +886-7-3617141 (ext. 23606) (C.-Y.H.)

+ These authors contributed equally to this work.

\section{check for} updates

Citation: Shiao, W.-C.; Wu, T.-C.; Kuo, C.-H.; Tsai, Y.-H.; Tsai, M.-L.; Hong, Y.-H.; Huang, C.-Y. Physicochemical and Antioxidant Properties of Gelatin and Gelatin Hydrolysates Obtained from Extrusion-Pretreated Fish (Oreochromis sp.) Scales. Mar. Drugs 2021, 19, 275. https://doi.org/ $10.3390 /$ md19050275

Academic Editor: Bill J. Baker

Received: 22 April 2021

Accepted: 11 May 2021

Published: 14 May 2021

Publisher's Note: MDPI stays neutral with regard to jurisdictional claims in published maps and institutional affiliations.

Copyright: (c) 2021 by the authors. Licensee MDPI, Basel, Switzerland. This article is an open access article distributed under the terms and conditions of the Creative Commons Attribution (CC BY) license (https:/ / creativecommons.org/licenses/by/ $4.0 /)$.

\begin{abstract}
Fish gelatin and its hydrolysates exhibit a variety of biological characteristics, which include antihypertensive and antioxidant properties. In this study, fish gelatins were extracted from extrusionpretreated tilapia scales, and then subjected to analyses to determine the physicochemical properties and antioxidant activity of the extracted gelatins. Our findings indicate that TSG2 (preconditioned with $1.26 \%$ citric acid) possessed the greatest extraction yield, as well as higher antioxidant activities compared with the other extracted gelatins. Hence, TSG2 was subjected to further hydrolyzation using different proteases and ultrafiltration conditions, which yielded four gelatin hydrolysates: TSGH1, TSGH2, TSGH3, and TSGH4. The results showed that TSGH4 (Pepsin + Pancreatin and ultrafiltration $<3000 \mathrm{Da}$ ) had a higher yield and greater antioxidant activity in comparison with the other gelatin hydrolysates. As such, TSGH4 was subjected to further fractionation using a Superdex peptide column and two-stage reverse-phase column HPLC chromatography, yielding a subfraction TSGH4-6-2-b, which possessed the highest 2,2-diphenyl-1-picrylhydrazyl (DPPH) scavenging activity compared with the other fractions. Further LC-ESI/MS/MS analysis of TSGH46-2-b suggested two novel peptides (GYDEY and EPGKSGEQGAPGEAGAP), which could have potential as naturally-occurring peptides with antioxidant properties. These promising results suggest that these antioxidant peptides could have applications in food products, nutraceuticals, and cosmetics.
\end{abstract}

Keywords: antioxidant; enzyme digestion; extrusion; fish scales; gelatin; gelatin hydrolysate; Oreochromis; pepsin; pancreatin; tilapia

\section{Introduction}

Oxidation is a common reaction that occurs in the cells of all living organisms, and therefore, antioxidant activity is an especially important component of normal cellular metabolism [1]. In aerobic organisms, the formation of free radicals is unavoidable. Normal aerobic metabolism involves the production of superoxide anion $\left({ }^{\bullet} \mathrm{O}^{2-}\right)$ and hydroxyl radical $\left({ }^{\bullet} \mathrm{OH}\right)$, which are unwanted metabolic by-products [2]. Free radicals are known to react quickly with other groups and substances, resulting in a wide range of deleterious effects on physiological processes and food [3]. Hence, oxidative stress is thought to play a 
role in the pathology of a number of human diseases and conditions, including diabetes, atherosclerosis, aging, neurodegenerative disorders, and cancer [4]. As certain synthetic antioxidants, such as butylated hydroxyanisole (BHA), butylated hydroxytoluene (BHT), t-butylhydroquinone (TBHQ), and propyl gallate (PG), may be negatively perceived by consumers and could pose health risks [5], there is a need for antioxidants, especially ones with nutritional and therapeutic properties, that can be derived from naturally-occurring substances [6-9].

Gelatin is widely utilized for a range of applications in the biomedical, pharmaceutical, food, cosmetic, and leather industries [10]. In certain parts of the world, the extraction of gelatin from bovine and porcine by-products is not permitted due to the risk of bovine spongiform encephalopathy, swine foot-and-mouth disease (FMD), or for religious reasons [11]. As a consequence, there has been a gradual increase in the use of fish by-products, including skin, bones, fins, and scales, as alternative sources of gelatin. Fish by-products offer a number of advantages for the production of gelatin, such as proven safety and wide availability. Gelatins containing lower molecular weight peptides such as gelatin hydrolysates have been shown to exhibit greater biological activities [12]. Furthermore, gelatin hydrolysates are valued in the food and pharmaceutical industries due to their ability to benefit various aspects of health, such as reduce oxidation and mitigate hypertension. Thus, there is considerable interest in using gelatin hydrolysates as functional food additives [13]. The use of fish gelatin containing bioactive peptides to produce hydrolysates has been demonstrated to be an effective method of creating value-added materials, and highlights the potential of fish gelatin for other possible applications [14].

The process of extrusion involves a high-temperature bioreaction that is short in duration and comprises mixing, heating, shearing, pressurizing, and shaping. During the extrusion process, raw materials are subjected to mechanical shearing at a high temperature and a low moisture content. This results in extruded products with highly modified properties, including microstructure, texture, flavor, and color [15]. It has been shown that extrusion can be used to pretreat rice straw, whereby enzymatic hydrolysis accelerates the saccharification of the rice straw [16]. Soybean dregs can be also extruded to reduce the amount of insoluble dietary fiber (IDF) and increase the soluble dietary fiber (SDF) contained in soybean residues [17]. In our previous study, we pretreated fish scales using extrusion, which enhanced the separation of collagen and hydroxyapatite $[8,18]$. These results demonstrate that extrusion technology is a powerful tool which can be used to pretreat raw materials, thereby enhancing and shortening the duration of subsequent processing.

Tilapia is a tropical teleost and one of the most common fish species used in aquaculture in Taiwan. Since 1978, when tilapia farming was first introduced in Taiwan, annual production has steadily increased, and in 2018, tilapia production totaled 65,000 $\mathrm{t}$ [19]. In this study, we aimed to explore the potential use of gelatin and gelatin hydrolysates obtained from single-screw extrusion pretreated tilapia scales. The extrusion pretreatment process boosted the extraction yield of fish scale-derived gelatin. In addition, the physicochemical and antioxidant properties of gelatin and its hydrolysates were investigated. To the best of our knowledge, the present study is the first investigation of gelatin hydrolysates obtained from tilapia scales pretreated by single-screw extrusion. Herein, we explore the potential applications of gelatin hydrolysates and discuss the possibility that antioxidant peptides could be of industrial value in the production of food, cosmetics, and nutraceuticals.

\section{Results and Discussion}

\subsection{Preparation of TSG1-6 from Extrusion-Pretreated Tilapia Scales}

Tilapia scales (TS) were obtained from a local fishery located in southern Taiwan. The chemical composition of TS was as follows: $43.8 \pm 0.4 \%$ protein, $40.0 \pm 0.5 \%$ ash, $11.5 \pm 0.8 \%$ water, $4.76 \pm 0.8 \%$ carbohydrate, and $0.02 \pm 0.00 \%$ lipid. The ash was predominantly composed of hydroxyapatite [20]. TS contained a large proportion of protein $(43.8 \%)$, suggesting that it could be a good source of gelatin, a denatured form of colla- 
gen. However, collagen contained in fish scales is bound tightly to hydroxyapatite, and thus, it is difficult to separate the two substances. In previous research, we developed an extrusion-pretreatment method that is capable of facilitating the separation of hydroxyapatite and collagen. This process significantly enhances the amount of gelatin that can be extracted from fish scales [18]. The extraction process was performed once the extrudates had been dried. All of the conditions for the extraction of gelatin from TS extrudates were set at $50{ }^{\circ} \mathrm{C}$ for $1 \mathrm{~h}$. Table 1 shows that the extruded samples TSG2, TSG4, and TSG6 had significantly greater extraction yields compared with the non-extruded samples (TSG1, TSG3, and TSG5). The fold increases between TSG1 and TSG2, TSG3 and TSG4, and TSG5 and TSG6 were approximately $10.6(22.2 / 2.10=10.6), 8.85(19.3 / 2.18=8.85)$, and $6.10(13.0 / 2.13=6.10)$, respectively. Taken together, the data show that TSG2 accounted for the greatest incremental fold increase compared with TSG4 and TSG6. Hence, TSG2 was found to be the best candidate for further development of a commercially produced gelatin owing to its high yield. The extruded samples TSG2, TSG4, and TSG6 exhibited the largest extraction yields, and thus, further analyses were conducted to characterize their physicochemical properties.

Table 1. Pretreatment conditions, extrusion variables, extraction variables, and extraction yields of tilapia scale gelatins for TSG1-6.

\begin{tabular}{|c|c|c|c|c|c|c|}
\hline Pretreatments & TSG1 & TSG2 & TSG3 & TSG4 & TSG5 & TSG6 \\
\hline Pretreatment solvent & - & - & - & - & $0.1 \mathrm{~N} \mathrm{NaOH}$ & $0.1 \mathrm{~N} \mathrm{NaOH}$ \\
\hline Variables of Extrusion & TSG1 & TSG2 & TSG3 & TSG4 & TSG5 & TSG6 \\
\hline Preconditioning solvent & $\begin{array}{c}1.26 \% \\
\text { citric acid }\end{array}$ & $\begin{array}{c}1.26 \% \\
\text { citric acid }\end{array}$ & $\begin{array}{c}9.37 \% \\
\text { acetic acid }\end{array}$ & $\begin{array}{c}9.37 \% \\
\text { acetic acid }\end{array}$ & $\begin{array}{c}1.26 \% \\
\text { acitric acid }\end{array}$ & $\begin{array}{c}1.26 \% \\
\text { citric acid }\end{array}$ \\
\hline Feed moisture (\%) & - & 27 & - & 27 & - & 27 \\
\hline Feed rate $(\mathrm{kg} / \mathrm{h})$ & - & 11.4 & - & 11.4 & - & 11.4 \\
\hline Barrel temperature $\left({ }^{\circ} \mathrm{C}\right)$ & - & 135 & - & 135 & - & 135 \\
\hline Screw speed (rpm) & - & 360 & - & 360 & - & 360 \\
\hline Die diameter (mm) & - & 3 & - & 3 & - & 3 \\
\hline $\begin{array}{c}\text { Variables of Water } \\
\text { Extraction }\end{array}$ & TSG1 & TSG2 & TSG3 & TSG4 & TSG5 & TSG6 \\
\hline Extraction temperature $\left({ }^{\circ} \mathrm{C}\right)$ & 50 & 50 & 50 & 50 & 50 & 50 \\
\hline Extraction time $(\mathrm{h})$ & 1 & 1 & 1 & 1 & 1 & 1 \\
\hline Extraction Yield of Gelatins & TSG1 $^{2}$ & TSG2 $^{2}$ & TSG3 $^{2}$ & TSG4 $^{2}$ & TSG5 $^{2}$ & TSG6 $^{2}$ \\
\hline Extraction yield (\%) ${ }^{1}$ & $2.10 \pm 0.03^{a}$ & $22.2 \pm 1.0^{\mathrm{d}}$ & $2.18 \pm 0.09^{a}$ & $19.3 \pm 0.4^{\mathrm{c}}$ & $2.13 \pm 0.03^{a}$ & $13.0 \pm 0.2^{b}$ \\
\hline
\end{tabular}

-, not adopted; ${ }^{1}$ The values are expressed as g protein $/ 100 \mathrm{~g}$ crude protein content of tilapia fish scales, dry basis; ${ }^{2}$ Values are mean $\pm \mathrm{SD}$ $(\mathrm{n}=3)$; values in the same row with varying letters $\left(\mathrm{a}, \mathrm{b}, \mathrm{c}\right.$, and $\left.{ }^{\mathrm{d}}\right)$ differ $(p<0.05)$.

\subsection{Physicochemical Properties of TSG2, TSG4, and TSG6}

The physicochemical characteristics of the gelatin extracts TSG2, TSG4, and TSG6 were analyzed to determine color, viscosity, ash, $\mathrm{pH}$, bloom gel strength, DSC, and fishy odor. The color differences among TSG2, TSG4, and TSG6 were investigated by measuring Hunterlab $L, a$, and $b$ values, and whiteness index. There were significant differences in $L, a$, and $b$ values, and whiteness index among the three gelatin extracts (Table 2). TSG6 had the highest whiteness index, followed by TSG2 and TSG4. These findings show that pretreatment by $\mathrm{NaOH}$ and preconditioning by citric acid induced an observable whitening of the gelatin extracts. Whiter gelatin extracts generally have better commercial potential. Regarding ash contents, the values for TSG2, TSG4, and TSG6 were $1.75 \% \pm 0.06 \%$, $3.58 \% \pm 0.27 \%$, and $3.33 \% \pm 0.09 \%$, respectively (Table 2). Overall, TSG2 exhibited the lowest ash content, indicating it had the greatest purity among the extracted gelatins, and the $\mathrm{pH}$ values (in 6.67\% solution) of TSG2, TSG4, and TSG6 were 7.2, 6.2, and 9.9, respectively (Table 2). The highest $\mathrm{pH}$ value seen in TSG6 could be attributable to the $0.1 \mathrm{~N} \mathrm{NaOH}$ pretreatment. The quality of a gelatin is primarily assessed according to its 
gel strength [18]. Differences in gel strength among gelatin extracts can potentially be attributed to fish species, biomaterial (skin, bone, or scales), composition of amino acids, and the size of protein chains [21]. In this study, TSG6 exhibited the greatest bloom gel strength (202 $\pm 0 \mathrm{~g})$, followed by TSG2 (185 $\pm 5 \mathrm{~g})$ and TSG4 (157 $\pm 5 \mathrm{~g})$ (Table 2). Compared with previous research, the gel strength of TSG2 and TSG6 in the current research was superior to the most commonly reported fish-derived gelatins, including Nile perch bone (179 and $134 \mathrm{~g}$, respectively, for young and adult fish) [21], Atlantic salmon skin (108 g) and cod skin (71 g) [22], giant catfish skin (153.0 g) and calf skin (134.8 g) [23], bigeye snapper skin (105.7 g) [24], and sin croaker (125 g) and shortfin scad (177 g) [25]. As such, the high gel strength of TSG2 and TSG6 suggests they may have potential for commercial development. Table 2 displays the viscosity of gelatin sample solutions TSG2, TSG4, and TSG6. TSG2 and TSG6 exhibited higher viscosity compared with TSG4, indicating that TS preconditioning using citric acid solution can enhance its viscosity. The viscosity of gelatin samples may vary according to molecular weight and molecular size distribution of proteins [26]. Viscosity is regarded as the second most important commercial physical characteristic of collagen-based products [27]. Typically, gelatins with a higher viscosity have a greater potential for commercial use. The viscosities of the extracted gelatins TSG2, TSG4, and TSG6 ranged from 8.10 to $9.77 \mathrm{cps}$ (measured at a concentration of $6.67 \%$ and a temperature of $60^{\circ} \mathrm{C}$ ), as compared to previously reported results from lizardfish scales, which ranged from 3.14 to $5.80 \mathrm{cps}$ (concentration $6.67 \%$; temp $25^{\circ} \mathrm{C}$ ) [28]. Although the measuring temperatures were different, gelatin solution at higher temperatures normally possesses lower viscosity, and thus, TSG2, TSG4, and TSG6 had greater viscosities than those extracted from lizardfish scales. The DSC results of TSG2, TSG4, and TSG6 are shown in Table 2. DSC analysis can be performed using rehydrated samples (rehydrated in $0.05 \mathrm{M}$ acetic acid at a sample/solution ratio of 1:40 (w/v)) [29] or solid state [30]. When a sample is analyzed in a solid state, there are usually two endothermal peaks $\left(T_{\max }=77\right.$ and $121^{\circ} \mathrm{C}$ ) [30]. In the present investigation, we utilized the solid state of gelatins for DSC analysis. It was found that two distinct endothermal peaks on the DSC thermograms of TSG2, TSG4, and TSG6 (Table 2). The first peak $\left(T_{\max 1}\right)$ can be attributed to the thermal denaturation temperature of the sample, while the second peak $\left(T_{\max 2}\right)$ is attributable to the ongoing conformational changes and subsequent destruction of materials [30]. The comparatively high denaturation parameters of $T_{\max 1}$ and $\mathrm{H} 1$ may explain the high thermal stability of collagenous products. In Table 2 , the $T_{\max 1}$ of TSG2 $\left(79.0^{\circ} \mathrm{C}\right)$, TSG4 $\left(57.9^{\circ} \mathrm{C}\right)$, and TSG6 $\left(62.6^{\circ} \mathrm{C}\right)$ are displayed. The total H1 values of TSG2, TSG4, and TSG6 were $1.40,8.01$, and $3.37 \mathrm{~J} / \mathrm{g}$, respectively. A greater $T_{\max 1}$ was observed in TSG2 compared with that found in TSG4 and TSG6. The higher thermal stability of TSG2 indicates that it would have a broader range of potential applications. Moreover, the $T_{\max 2}$ values among TSG2, TSG4, and TSG6 were not markedly different. The odor and overall acceptability of gelatin extracts TSG2, TSG4, and TSG6 were assessed using a nine-point hedonic scale, with 1 indicating "very bad" and 9 indicating "very good." The results shown in Table 2 demonstrate that for odor (in solution), odor (in powder), and overall acceptability, gelatin samples TSG2 (preconditioned with citric acid solution) and TSG6 (preconditioned with citric acid solution) had better hedonic scores compared with TSG4 (preconditioned with acetic acid solution). These results clearly show that TS preconditioned using citric acid solution exhibited superior odor acceptability compared with that achieved with acetic acid solution. We speculate that, due to the distinctive pungent odor of acetic acid, the TSG4 adversely enhanced the unpleasant odor, and thus, received the lowest overall odor acceptability. In summary, TSG2 was found to have high values for whiteness, gelatin purity, bloom gel strength, viscosity, thermal stability, and odor acceptability. Hence, TSG2 would be the obvious choice for further commercial development. 
Table 2. Physicochemical properties of TSG2, TSG4, and TSG6.

\begin{tabular}{|c|c|c|c|}
\hline $\begin{array}{c}\text { Physicochemical } \\
\text { Properties }\end{array}$ & TSG $^{1}$ & TSG $^{1}$ & TSG $^{1}$ \\
\hline$L$ & $82.3 \pm 0.0^{b}$ & $74.5 \pm 0.1^{\mathrm{a}}$ & $93.2 \pm 0.1^{c}$ \\
\hline$a$ & $0.63 \pm 0.03^{b}$ & $1.52 \pm 0.03^{c}$ & $-1.39 \pm 0.04^{\mathrm{a}}$ \\
\hline$b$ & $9.27 \pm 0.09^{b}$ & $10.0 \pm 0.0^{\mathrm{c}}$ & $5.42 \pm 0.02^{\mathrm{a}}$ \\
\hline Whiteness index & $80.0 \pm 0.0^{b}$ & $72.5 \pm 0.0^{\mathrm{a}}$ & $91.2 \pm 0.0^{c}$ \\
\hline Ash $(\%)$ & $1.75 \pm 0.06^{\mathrm{a}}$ & $3.58 \pm 0.27^{b}$ & $3.33 \pm 0.09^{b}$ \\
\hline $\mathrm{pH}$ & 7.2 & 6.2 & 9.9 \\
\hline Bloom gel strength $(\mathrm{g})$ & $185 \pm 5^{b}$ & $157 \pm 5^{\mathrm{a}}$ & $202 \pm 0^{c}$ \\
\hline Viscosity (cps) & $9.77 \pm 0.12^{b}$ & $8.10 \pm 0.24^{\mathrm{a}}$ & $9.53 \pm 0.17^{b}$ \\
\hline$T_{\max 1}\left({ }^{\circ} \mathrm{C}\right)$ & 79.0 & 57.9 & 62.6 \\
\hline$T_{\max 2}\left({ }^{\circ} \mathrm{C}\right)$ & 176 & 182 & 179 \\
\hline $\mathrm{H} 1(\mathrm{~J} / \mathrm{g})$ & 1.40 & 8.01 & 3.37 \\
\hline $\mathrm{H} 2(\mathrm{~J} / \mathrm{g})$ & 116 & 166 & 152 \\
\hline Odor (in solution) ${ }^{2}$ & $5.21 \pm 1.68^{b}$ & $4.04 \pm 2.07^{\mathrm{a}}$ & $5.38 \pm 1.60^{b}$ \\
\hline Odor (in powder) ${ }^{2}$ & $6.08 \pm 1.15^{b}$ & $3.17 \pm 1.97^{\mathrm{a}}$ & $6.46 \pm 1.08^{b}$ \\
\hline Overall acceptability $^{2}$ & $6.58 \pm 1.55^{b}$ & $5.08 \pm 1.85^{\mathrm{a}}$ & $5.42 \pm 1.35^{\mathrm{a}}$ \\
\hline
\end{tabular}

${ }_{1}^{1}$ Values are mean $\pm \mathrm{SD}(\mathrm{n}=3)$; values in the same row with varying letters (in ${ }^{\mathrm{a}},{ }^{\mathrm{b}}$, and $\left.{ }^{\mathrm{c}}\right)$ differ $(p<0.05)$.

${ }^{2}$ Sensory attributes were rated on a nine-point hedonic scoring scale $(1=$ very bad, $5=$ moderate, $9=$ very good $)$.

\subsection{Structure and Molecular Weights of Extracted Gelatins TSG2, TSG4, and TSG6}

FTIR and HPLC gel filtration chromatography were used to analyze the structure and MW profiles of TSG2, TSG4, and TSG6. It has been shown previously that the FTIR spectra of collagenous products exhibit five major absorption bands in the amide band region, as follows: $3304-3315 \mathrm{~cm}^{-1}$ (amide A: NH stretch, coupled with hydrogen bonding), 2922-2940 $\mathrm{cm}^{-1}$ (amide B: asymmetric stretching vibration of $=\mathrm{C}-\mathrm{H}$ and $-\mathrm{NH}_{3}{ }^{+}$), $1644-1653 \mathrm{~cm}^{-1}$ (amide I: stretching vibration of $\mathrm{C}=\mathrm{O}$ involved in hydrogen bonds), $1541-1548 \mathrm{~cm}^{-1}$ (amide II: NH bend, coupled with CN stretch), and 1237-1239 $\mathrm{cm}^{-1}$ (amide III: NH bend) [31-34]. The amide A, amide B, and $-\mathrm{CH}_{2}$ stretch $\left(2853 \mathrm{~cm}^{-1}\right)$ bands showed a tendency to join (Figure 1), which may be due to the dimeric intermolecular associations of carboxylic groups [33]. In the present study, the FTIR spectra of TSG2, TSG4, and TSG6 showed the distinct characteristic peaks of amides A and B, as well as amides I, II, and III (Figure 1). There was little difference in the major absorption bands at amide A, amide B, amide I, amide II, and amide III among TSG2, TSG4, and TSG6, suggesting that their structural properties were not notably changed. In addition, the band at $2355 \mathrm{~cm}^{-1}$ was visible in TSG2 and TSG4, which may correspond to carbon dioxide adsorption on the sample surface [35]. The MW profiles of TSG2, TSG4, and TSG6 are displayed in Figure 2. The $\alpha$ chain (approximately $116.5 \mathrm{kDa}$ ) and $\beta$ component (approximately $255.5 \mathrm{kDa}$ ) were observed in TSG2, the $\alpha$ chain (approximately $116.5 \mathrm{kDa}$ ) and $\gamma$ component (approximately $417.3 \mathrm{kDa}$ ) were visible in TSG4, and the $\alpha$ chain (approximately $116.5 \mathrm{kDa}$ ) and $\gamma$ component (approximately $417.3 \mathrm{kDa}$ ) were detected in TSG6. Taken together, the results of our analyses of TSG2, TSG4, and TSG6 and the characteristic MW profiles of these gelatin samples were consistent with previously reported findings [18].

\subsection{Antioxidant Activities of TSG2, TSG4, and TSG6}

The antioxidant properties of TSG2, TSG4, and TSG6 were assessed using 2,2-diphenyl1-picrylhydrazyl (DPPH), 2,20-azino-bis (3-ethylbenzothiazoline-6-sulphonic acid) diammonium salt (ABTS), and reducing power analyses. Figure $3 \mathrm{~A}$ shows the scavenging effects of TSG2, TSG4, and TSG6 and BHA (positive control) on DPPH free radicals. DPPH scavenging characteristics were detected in all of the gelatin extracts, TSG2, TSG4, and TSG6. Moreover, TSG2 exhibited greater DPPH radical scavenging activity compared with those of TSG4 and TSG6. ABTS radical assay is a powerful analytic tool that is capable of measuring levels of hydrogen-donating antioxidants. The technique employs a process whereby the radical is quenched forming an ABTS radical complex [36,37]. Figure 3B 
shows the ABTS ${ }^{+}$scavenging activities of gelatin extracts TSG2, TSG4, and TSG6. All of the gelatin extracts TSG2, TSG4, and TSG6 exhibited dose-dependent ABTS ${ }^{+}$scavenging activities. Overall, TSG6 showed the greatest $\mathrm{ABTS}^{+}$scavenging activity, followed by TSG2, with TSG4 having the least activity. The reducing power of a substance is largely related to the presence of reductones (antioxidants), which donate hydrogen atoms, resulting in disruption of the free radical chain, and this process confers an antioxidant effect. Antioxidant components in samples lead to a reduction of the $\mathrm{Fe}^{3+} /$ ferricyanide complex to the $\mathrm{Fe}^{2+}$ form, which can be assessed by detecting the formation of Prussian blue at $700 \mathrm{~nm}$ [38]. The reducing power of gelatin extracts TSG2, TSG4, and TSG6 and BHA (positive control) is shown in Figure 3C. Great reducing power was found in all of the gelatin extracts and increased in proportion to their concentration. TSG2 had the greatest reducing power, followed by TSG6 and TSG4, despite the lack of any significant difference $(p>0.05)$ between TSG2 and TSG6. In summary, gelatin extracts that were preconditioned using citric acid (TSG2 and TSG6) had higher antioxidant activities compared with those prepared using acetic acid (TSG4). Among the tested gelatin extracts, TSG2 exhibited the strongest antioxidant activities and was, therefore, selected for further analyses.

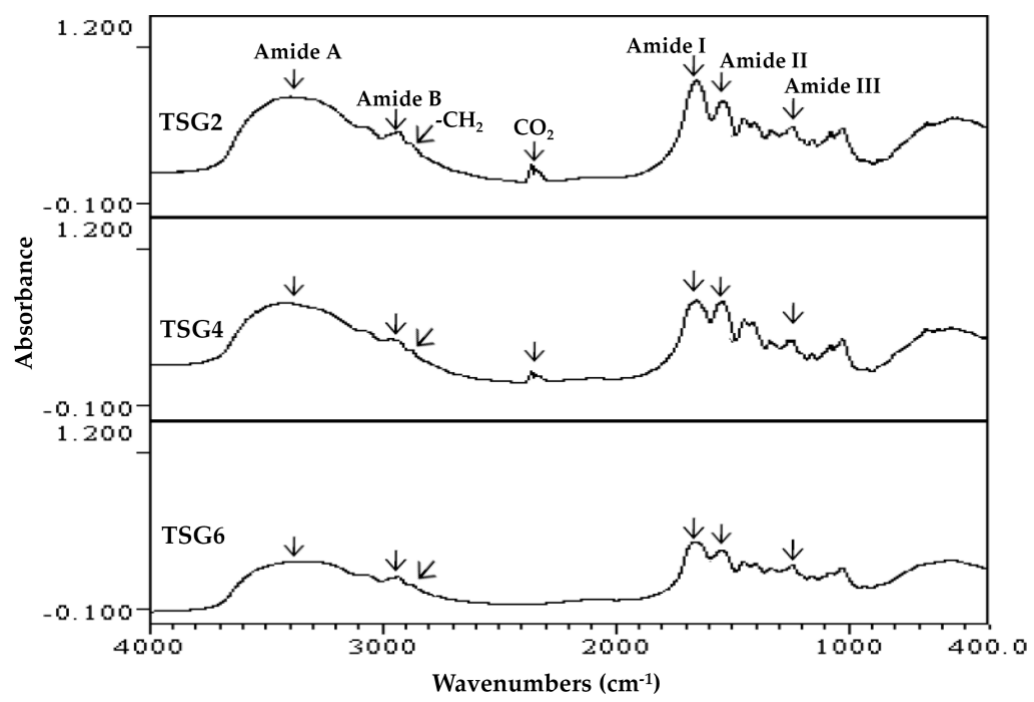

Figure 1. FTIR spectra of TSG2, TSG4, and TSG6. Absorption bands at amide A, amide $\mathrm{B},-\mathrm{CH}_{2}, \mathrm{CO}_{2}$, amide I, amide II, and amide III are indicated.

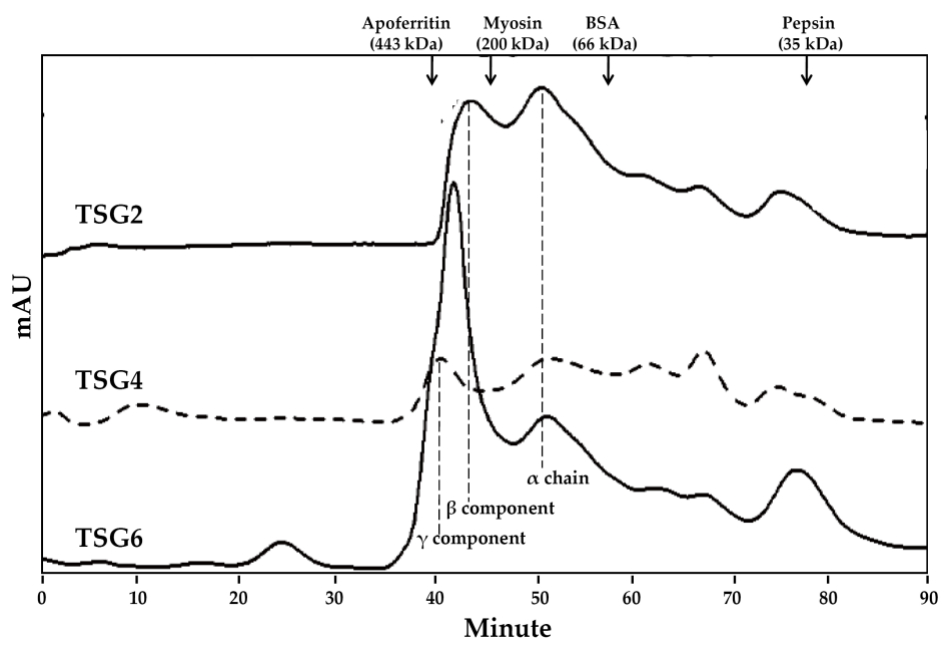

Figure 2. Size exclusion chromatographic profiles of TSG2, TSG4, and TSG6. Apoferritin (443 kDa), myosin $(200 \mathrm{kDa})$, BSA $(66 \mathrm{kDa})$, and pepsin $(35 \mathrm{kDa})$ were used as standard proteins. 

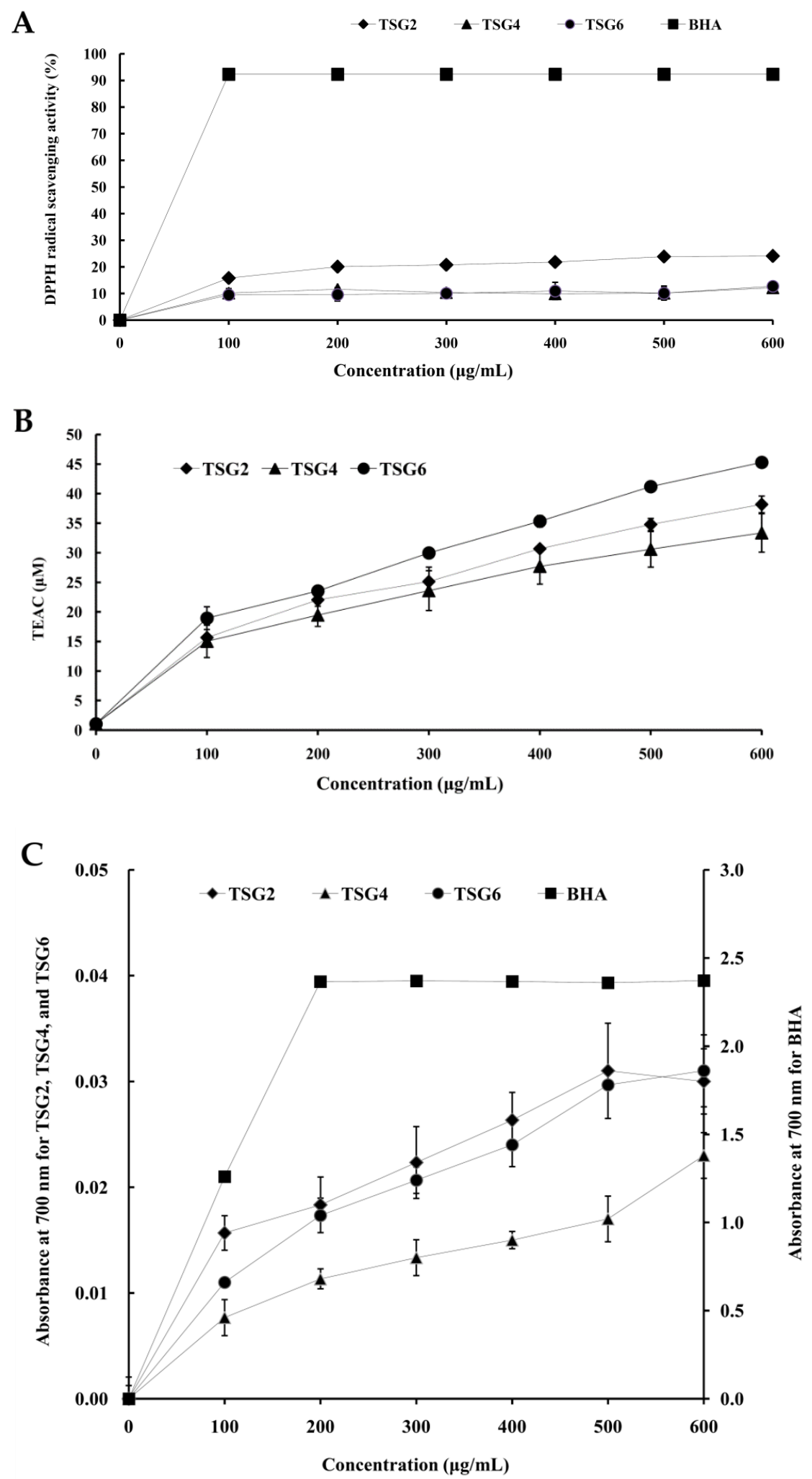

Figure 3. Antioxidant activities of TSG2, TSG4, and TSG6. (A) DPPH radical scavenging activities of TSG2, TSG4, TSG6, and BHA. (B) ABTS radical scavenging activities of TSG2, TSG4, and TSG6. (C) Reducing power of TSG2, TSG4, TSG6, and BHA. 


\subsection{Preparation of Gelatin Hydrolysates TSGH1, TSGH2, TSGH3, and TSGH4 and Analyses of Antioxidant Activity}

Enzymatic hydrolysis is a commonly used tool in the production of food-grade protein hydrolysates. This process results in the release of bioactive peptides from their protein precursors [8]. It is an environmentally friendly technique because it requires little to no toxic chemicals or solvents. In the current study, the gelatin extract TSG2 was selected for hydrolysis using pepsin and pancreatin (industrial food-grade proteinases) in order to obtain gelatin hydrolysates. Table 3 shows the results of the four gelatin hydrolysates, (TSGH1, TSGH2, TSGH3, and TSGH4) obtained using different enzymes and ultrafiltration conditions. The size of MW is thought to be the most important determinant of the biological functions of protein hydrolysates [39]. It can be seen in Table 3 that for TSGH1, the major MW distributions ranged from 2883-37,466 Da and the peak MW was 24,012 Da; for TSGH2 the range was $1800-37,466 \mathrm{Da}$, with a peak MW of 18,006 Da; TSGH3 ranged from 96-1184 Da and the peak MW was $131 \mathrm{Da}$; for TSGH4, range was 74-21,625 Da, with a peak MW of $1315 \mathrm{Da}$. The aforementioned results demonstrate that the MWs of TSGH1 (ultrafiltration > $3000 \mathrm{Da}$ ) and TSGH2 (ultrafiltration > $3000 \mathrm{Da}$ ) were greater and the peak MWs were located at 24,012 and 18,006 Da, respectively. However, TSGH3 (ultrafiltration < $3000 \mathrm{Da}$ ) and TSGH4 (ultrafiltration < $3000 \mathrm{Da}$ ) had smaller MWs with peaks located at 131 and $1315 \mathrm{Da}$, respectively. Furthermore, the gel filtration graph (Supplementary Figure S1) of TSGH1-4 shows the TSGH3 yield was very low, indicating that for hydrolysis of TSG2, pepsin alone is insufficient. In contrast, TSGH4 was obtained from the digestion of TSG2 by two enzymes (pepsin + pancreatin), and thus, it had a higher production yield. In addition, DPPH, ABTS, and reducing power assays were used to assess the antioxidant activities of TSGH1, TSGH2, TSGH3, and TSGH4. Table 3 shows that, in general, the samples with larger amounts of low-molecular weight hydrolysates, i.e., TSGH3 and TSGH4, possessed greater DPPH and ABTS scavenging activities and reducing power compared with the other samples, i.e., TSGH1 and TSGH2. Compared with TSGH3, TSGH4 had a greater production yield and was, thus, selected for further HPLC fractionation experiments.

Table 3. Variables involved in the preparation of gelatin hydrolysates, molecular weight distribution, and antioxidant activities of TSGH1, TSGH2, TSGH3, and TSGH4.

\begin{tabular}{|c|c|c|c|c|}
\hline Process Variables & TSGH1 & TSGH2 & TSGH3 & TSGH4 \\
\hline Gelatin source & TSG2 & TSG2 & TSG2 & TSG2 \\
\hline Enzyme used & Pepsin & Pepsin + Pancreatin & Pepsin & Pepsin + Pancreatin \\
\hline Digestion conditions & $\mathrm{pH} 2.0,37^{\circ} \mathrm{C}, 4 \mathrm{~h}$ & $\begin{array}{c}\mathrm{pH} 2.0,37^{\circ} \mathrm{C}, 4 \mathrm{~h} \text { (for } \\
\text { Pepsin); } \mathrm{pH} 7.0,37^{\circ} \mathrm{C}, \\
4 \mathrm{~h} \text { (for Pancreatin) }\end{array}$ & $\mathrm{pH} 2.0,37^{\circ} \mathrm{C}, 4 \mathrm{~h}$ & $\begin{array}{c}\mathrm{pH} 2.0,37^{\circ} \mathrm{C}, 4 \mathrm{~h} \text { (for } \\
\text { Pepsin); } \mathrm{pH} 7.0,37^{\circ} \mathrm{C} \text {, } \\
4 \mathrm{~h} \text { (for Pancreatin) }\end{array}$ \\
\hline Ultrafiltration condition & $>3000 \mathrm{Da}$ & $>3000 \mathrm{Da}$ & $<3000 \mathrm{Da}$ & $<3000 \mathrm{Da}$ \\
\hline Molecular Weight (MW) & TSGH1 & TSGH2 & TSGH3 & TSGH4 \\
\hline Peak MW ${ }^{1}(\mathrm{Da})$ & 24,012 & 18,006 & 131 & 1315 \\
\hline MW interval (Da) & $2883-37,466$ & $1800-37,466$ & $96-1184$ & $74-21,625$ \\
\hline Antioxidant Activities 1 & TSGH1 $^{2}$ & TSGH2 & TSGH3 & TSGH4 \\
\hline $\begin{array}{l}\text { DPPH scavenging } \\
\text { activity (\%) }\end{array}$ & $43.3 \pm 1.1^{\text {a } 3}$ & $44.4 \pm 3.6^{\mathrm{a}}$ & $84.0 \pm 0.3^{c}$ & $71.8 \pm 2.5^{b}$ \\
\hline TEAC $(\mu \mathrm{M})$ & $12.7 \pm 0.1^{\mathrm{a}}$ & $29.7 \pm 0.4^{c}$ & $27.6 \pm 0.2^{b}$ & $29.2 \pm 0.3^{c}$ \\
\hline Absorbance $(700 \mathrm{~nm})$ & $0.15 \pm 0.02^{a}$ & $0.24 \pm 0.01^{b}$ & $0.20 \pm 0.05^{a}$ & $0.23 \pm 0.01^{b}$ \\
\hline
\end{tabular}

${ }^{1}$ Peak MW: molecular weight of the highest peak; ${ }^{2}$ The concentration for TSGH1-4 was $10 \mathrm{mg} / \mathrm{mL} .{ }^{3}$ Values are mean \pm SD $(n=3)$; values in the same row with different letters (in ${ }^{\mathrm{a}}$, ${ }^{\mathrm{b}}$, and $\left.{ }^{\mathrm{c}}\right)$ differ significantly $(p<0.05)$. 


\subsection{Preparation of Fractionated Products using TSGH4 and Assessment of Their DPPH Scavenging Activities}

Gel filtration chromatography was used to separate the fractions with different MW distributions from TSGH4. In total, 12 fractions (TSGH4-1-TSGH4-12) were collected (Figure 4A) using gel filtration chromatography. These fractions were then assayed to determine their DPPH scavenging activity (Table 4). In the present study, we employed the DPPH free radical scavenging method to assess the antioxidant activities of fractionated gelatin hydrolysates due to the greater stability of free radicals and a short assay time [40]. The results showed that TSGH4-6 had the greatest DPPH scavenging activity among the 12 fractions that were analyzed (Table 4). RP-HPLC is an effective technique that uses the hydrophobic/hydrophilic peptide ratio to separate peptides in protein hydrolysates [41]. Two fractions (TSGH4-6-1 and TSGH4-6-2) were collected (Figure 4B) following RP-HPLC chromatography and were assayed to determine their DPPH scavenging activity (Table 4). The results showed DPPH scavenging activities in TSGH4-6-1 and TSGH4-6-2 were similar (Table 4). Hence, a second-run RP-HPLC chromatographic analysis of TSGH4-6-1 and TSGH4-6-2 was conducted. Three individual fractions (TSGH4-6-1-a, TSGH4-6-1-b, and TSGH4-6-1-c for TSGH4-6-1; and TSGH4-6-2-a, TSGH4-6-2-b, and TSGH4-6-2-c for TSGH46-2) were collected (Figure 4C) after RP-HPLC chromatography, and DPPH scavenging activity was assayed (Table 4). The results in Table 4 show that TSGH4-6-2-b had the greatest DPPH scavenging activity among the tested fractions, despite not being significantly different $(p>0.05)$ compared with those of TSGH4-6-1-b and TSGH4-6-2-c. In summary, following fractionation, the fractionated gelatin hydrolysates showed enhanced DPPH scavenging activities. TSGH4-6-2-b, which had the most potent DPPH scavenging activity, was selected for further LC-ESI/MS/MS analysis.
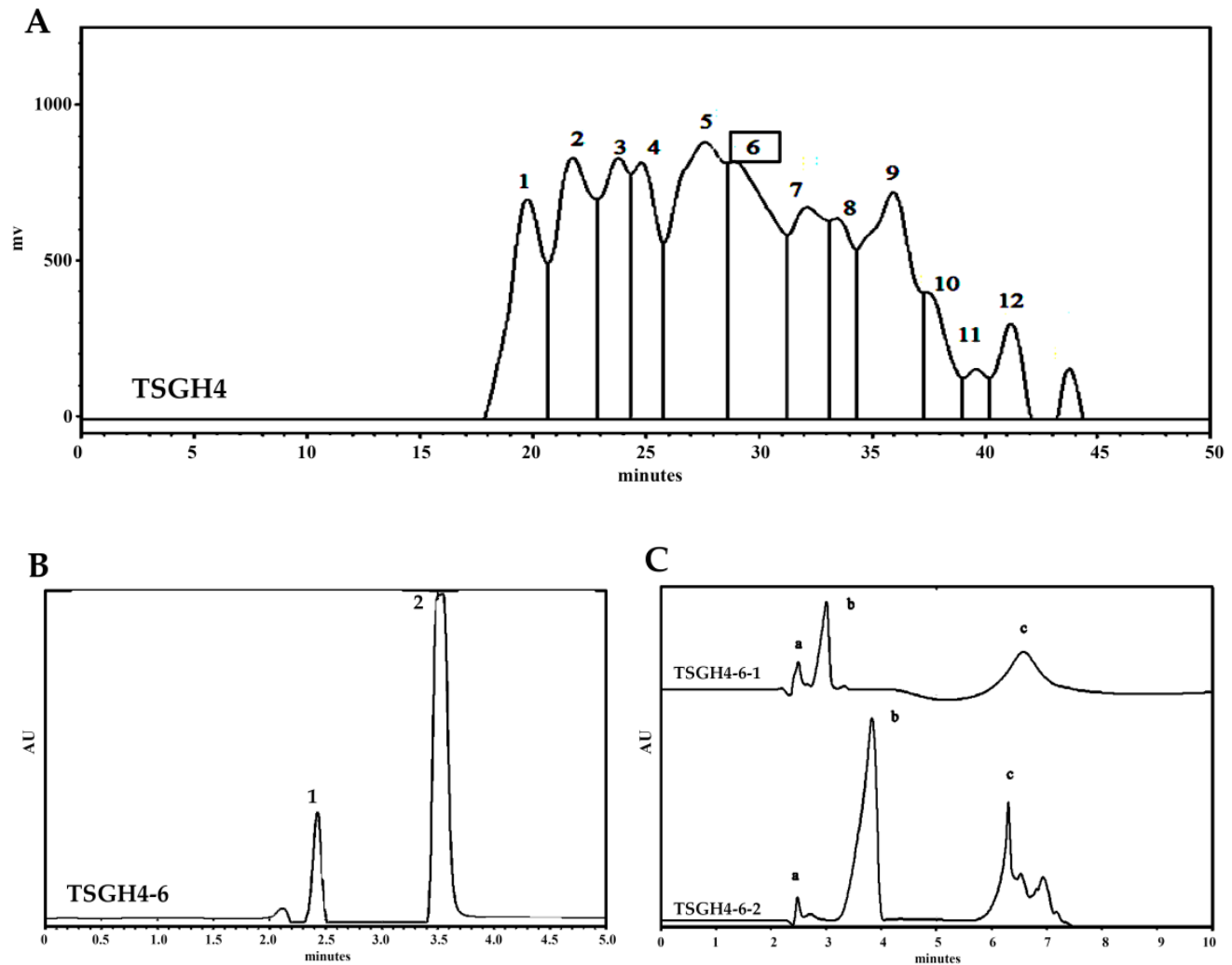

Figure 4. HPLC profiles for gelatin hydrolysates. (A) Superdex peptide chromatographic profiles of TSGH4. (B) RP-HPLC chromatographic profiles of TSGH4-6. (C) RP-HPLC chromatographic profiles of TSGH4-6-1 and TSGH4-6-2. 
Table 4. Peptide content and DPPH scavenging activity of fractionated products from TSGH4.

\begin{tabular}{|c|c|c|}
\hline Samples & Peptide Content $(\mu \mathrm{g} / \mu \mathrm{L})^{1}$ & $\begin{array}{l}\text { DPPH Scavenging Activity } \\
\text { (Vit } C \mathrm{ppm} / \mu \mathrm{g} \text { Peptide) }^{1}\end{array}$ \\
\hline \multicolumn{3}{|c|}{ TSGH4 separated by Superdex peptide column } \\
\hline TSGH4-1 & $0.13 \pm 0.00$ & $0.12 \pm 0.03$ \\
\hline TSGH4-2 & $0.08 \pm 0.00$ & $0.00 \pm 0.00$ \\
\hline TSGH4-3 & $0.08 \pm 0.00$ & $0.00 \pm 0.00$ \\
\hline TSGH4-4 & $0.15 \pm 0.00$ & $0.11 \pm 0.06$ \\
\hline TSGH4-5 & $0.13 \pm 0.00$ & $0.43 \pm 0.06$ \\
\hline TSGH4-6 & $0.16 \pm 0.05$ & $0.97 \pm 0.03$ \\
\hline TSGH4-7 & $0.31 \pm 0.00$ & $0.23 \pm 0.02$ \\
\hline TSGH4-8 & $0.15 \pm 0.00$ & $0.53 \pm 0.03$ \\
\hline TSGH4-9 & $0.13 \pm 0.00$ & $0.00 \pm 0.00$ \\
\hline TSGH4-10 & $0.69 \pm 0.01$ & $0.35 \pm 0.01$ \\
\hline TSGH4-11 & $0.15 \pm 0.00$ & $0.48 \pm 0.02$ \\
\hline TSGH4-12 & $0.14 \pm 0.00$ & $0.00 \pm 0.00$ \\
\hline \multicolumn{3}{|c|}{ TSGH4-6 separated by RP-HPLC C18 column } \\
\hline TSGH4-6-1 & $0.097 \pm 0.003$ & $1.17 \pm 0.05$ \\
\hline TSGH4-6-2 & $0.085 \pm 0.002$ & $1.17 \pm 0.06$ \\
\hline \multicolumn{3}{|c|}{ TSGH4-6-1 separated by RP-HPLC C18 column } \\
\hline TSGH4-6-1-a & $0.086 \pm 0.003$ & $1.22 \pm 0.14$ \\
\hline TSGH4-6-1-b & $0.089 \pm 0.004$ & $1.35 \pm 0.15$ \\
\hline TSGH4-6-1-c & $0.082 \pm 0.003$ & $0.80 \pm 0.08$ \\
\hline \multicolumn{3}{|c|}{ TSGH4-6-2 separated by RP-HPLC C18 column } \\
\hline TSGH4-6-2-a & $0.086 \pm 0.004$ & $1.13 \pm 0.19$ \\
\hline TSGH4-6-2-b & $0.090 \pm 0.004$ & $1.60 \pm 0.22$ \\
\hline TSGH4-6-2-c & $0.092 \pm 0.003$ & $1.39 \pm 0.09$ \\
\hline
\end{tabular}

${ }^{1}$ Values are mean $\pm \mathrm{SD}(\mathrm{n}=3)$.

\subsection{Potential Antioxidant Peptides in TSGH4-6-2-b by LC-ESI/MS/MS Analysis}

The fractionated gelatin hydrolysate TSGH4-6-2-b exhibited the greatest DPPH scavenging activity and was, thus, subjected to further LC-ESI/MS/MS analysis. The results are displayed in Table 5 . The most intense ions in the hydrolysate exhibited homology with the collagen molecules (collagen alpha-2(I) chain and collagen type I alpha 1). Moreover, Gly and Pro were the two major amino acids detected in the peptide sequences. Peptides responsible for the scavenging activity serve as electron donors and convert free radicals to more stable products and terminate the radical chain reaction [42]. The presence of certain amino acids in the hydrolysates increase the scavenging activities of peptides. Among the peptides, Trp, Tyr, and Met had the strongest antioxidant activity, followed by Cys, His, and Phe [43]. Furthermore, it was previously demonstrated that among the antioxidative peptides obtained from the enzymatic hydrolysates of tuna dark muscle by-product, Tyr, Pro, Glu and Asp were the key variables correlated with antioxidant activity [44]. Gelatin subfractions with peptides containing large amounts of Arg, Tyr, and Phe are also thought to possess higher antioxidant activity [12]. In addition, the presence of acidic amino Glu in the peptides could induce strong antioxidant effects, as a free electron is available for interaction with free radicals [45]. Peptides composed of hydrophobic amino acids coupled with Pro, Gln, Glu, and Ser have a strong antioxidant activity in the peptide sequence [46]. Based on these results, we suggested two peptide sequences (GYDEY and EPGKSGEQGAPGEAGAP) (Table 5) containing more of the abovementioned antioxidative amino acids, which could have potential as novel antioxidant peptides. Further research on the synthesis of the two novel antioxidant peptides and conducting in vivo experiments are required for confirmation of these findings. 
Table 5. A selection of the most intense ions corresponding to peptides in TSGH4-6-2-b by LC$\mathrm{ESI} / \mathrm{MS} / \mathrm{MS}$.

\begin{tabular}{ccc}
\hline Protein Origin & Molecular Mass $\mathbf{( + 1 )}$ & Peptide Sequence \\
\hline Collagen alpha-2(I) chain & 440.24 & GPLGP \\
& 442.26 & GPVGL \\
& 470.25 & LPGSP \\
511.28 & GPAGPL \\
543.27 & GELGPA \\
568.30 & GPAGPLG \\
592.27 & GPSGFAG \\
& 646.23 & GYDEY \\
778.40 & GLPGPPGPS \\
1194.57 & ADGNTGPAGPAGPL \\
& 1251.59 & GADGNTGPAGPAGPL \\
& 1268.59 & GPAGARGADGNTGPA \\
\hline Collagen type I alpha 1 & GSPGPDGNNGPAGPVG \\
\hline 4.60 & GPIGP \\
& 440.24 & LPGPS \\
& 510.25 & GPAGIP \\
& 543.28 & GEIGPA \\
& 568.30 & QPGLPG \\
& 568.30 & GPAGIPG \\
& 610.31 & VGPPGPS \\
& 994.50 & GPAGASGPAGPR \\
1075.51 & GAPGPPGPSGPQG \\
1307.62 & GETGPAGVPGPAGPSG \\
1330.67 & PGPAGATGAPGPQGPV \\
& 1538.70 & EPGKSGEQGAPGEAGAP \\
\hline
\end{tabular}

\section{Materials and Methods}

\subsection{Materials and Chemicals}

Tilapia fish scales were obtained from a fishery in southern Taiwan. Fresh fish scales were kept on ice and then immediately transported to our laboratory. Some of the fish scales were mixed with $0.1 \mathrm{~N} \mathrm{NaOH}$, and the mixture was then washed with tap water to attain a $\mathrm{pH}$ of 7.0. All of the fish scales were dried at $50{ }^{\circ} \mathrm{C}$ until a moisture content of less than $10 \%$ was obtained. Dried fish scales were then milled into a powder $(<20$ mesh) and stored at room temperature in aluminum foil bags until use. Pepsin, apoferritin, pancreatin, trypsin, myosin, aprotinin, glycine, glutathione, Gly-Gly-Gly, potassium ferricyanide, potassium bromide (KBr), trichloroacetic acid, DPPH, ABTS, 6-hydroxy-2,5,7,8-tetramethylchroman-2carboxylic acid (Trolox), and bovine serum albumin (BSA) were purchased from SigmaAldrich (St. Louis, MO, USA). Superdex 200 10/30 column (300 mm $\times 10 \mathrm{~mm}$ ID) and Superdex Peptide HR 10/30 column (300 mm $\times 10 \mathrm{~mm}$ ID) were purchased from GE Healthcare (Piscataway, NJ, USA). Inspire C18 column $(4.6 \mathrm{~mm} \times 250 \mathrm{~mm}, 5 \mu \mathrm{m})$ was purchased from Dikma Technologies Inc. (Lake Forest, CA, USA). All of the other chemicals used in experiments were of analytical grade and were purchased from Sigma-Aldrich (St. Louis, MO, USA).

\subsection{Extrusion-Cooking Pretreatment}

The extrusion operation variables are shown in Table 1. For TSG5 and TSG6, the fish scales were pretreated with $0.1 \mathrm{~N} \mathrm{NaOH}$ prior to extrusion, which has been demonstrated to remove non-collagenous proteins and eliminate any undesirable fishy odors [47]. Following pretreatment with $0.1 \mathrm{~N} \mathrm{NaOH}$, TSG5 and TSG6 were washed with water until the $\mathrm{pH}$ was neutral or slightly basic. Fish scale powder was utilized as the raw material and preconditioned by mixing with $1.26 \%$ citric acid or $9.37 \%$ acetic acid such that the final moisture content was $27 \%$. Extrusion cooking was conducted using a model single-screw extruder (Tsung Hsing Food Machinery, Kaohsiung, Taiwan) that was equipped with a 
screw diameter of $74 \mathrm{~mm}$, a screw length-to-diameter (L/D) ratio of 3.07:1, and a rounded die opening $(3 \mathrm{~mm})$ at the end of the extruder. Heating of the barrel was controlled using an electric heating element which jacketed the barrel and thermal probe. The barrel temperature was set at $135^{\circ} \mathrm{C}$. The screw speed was kept constant at $360 \mathrm{rpm}$. The feed rate was set at $11.4 \mathrm{~kg} / \mathrm{h}$ to ensure stable operation of the extruder. The extrudate was collected at the die end and kept at $50{ }^{\circ} \mathrm{C}$ in a hot air oven for $30 \mathrm{~min}$ in order to remove excess moisture. Once the extrusion-cooking procedure had been completed, the extrudate was ground into fine particles ( $<20$ mesh) and sealed in aluminum foil bags. It was stored at $4{ }^{\circ} \mathrm{C}$ until further use.

\subsection{Extraction of Gelatin from Non-Extruded Fish Scales and Fish Scale Extrudate}

The extraction operation variables are shown in Table 1. Non-extruded fish scale powder or fish scale extrudate powder was soaked in $\mathrm{ddH}_{2} \mathrm{O}$ using a sample ratio of 1:10 $(\mathrm{w} / \mathrm{v})$ and was then shaken in a water bath at $50{ }^{\circ} \mathrm{C}$ for $1 \mathrm{~h}$. The mixture was centrifuged at $10,200 \times g$ for $10 \mathrm{~min}$. The supernatant was collected and subjected to determination of its protein concentration using the Lowry method. It was then lyophilized and the gelatin products were obtained. The gelatin yield was expressed as the weight of the protein extracted by hot water/weight of crude protein fish scale content (dry basis) using Equation (1):

Yield $(\%)=[$ protein content of supernatant $(\mathrm{g} / \mathrm{mL}) \times$ volume of supernatant

$(\mathrm{mL})) /($ weight of crude protein content of fish scales $(\mathrm{g})$, dry basis) $] \times 100$

\subsection{Determination of Protein Concentration}

The Lowry assay was performed as described previously [48]. Calibration was conducted using different concentrations of stock BSA protein solution $(1 \mathrm{mg} / \mathrm{mL})$.

\subsection{Color Analysis}

The color of the gelatin samples that had been generated using various operating conditions were determined. Tristimulus color values, i.e., L (lightness), a (redness-greenness), and $b$ (yellowness-blueness) values, were assessed using an SA-2000 spectrophotometer (Nippon Denshoku, Tokyo, Japan). The data were recorded using at least three separate gelatin samples for each test point. The whiteness index (WI) was calculated using Equation (2):

$$
\text { Whiteness index }(\mathrm{WI})=100-\left((100-L)^{2}+a^{2}+b^{2}\right)^{0.5}
$$

\subsection{Chemical Composition Analyses}

The measurements of the moisture, fat, ash, and crude protein content were carried out using the following AOAC (1984) procedures [49]: moisture (\%) was measured by drying samples in an oven at $103{ }^{\circ} \mathrm{C}$ for $8 \mathrm{~h}$; crude fat (\%) was determined gravimetrically after extraction of Soxhlet with petroleum ether; crude ash (\%) was obtained by incineration in a muffle furnace at $580^{\circ} \mathrm{C}$ for $8 \mathrm{~h}$; and crude protein $(\mathrm{N} \times 5.95)(\%)$ was assessed using the Kjeldahl method following acid digestion.

\subsection{Determination of Gel Strength}

The bloom gel strength was analyzed using the British Standard 757: 1975 method [50] with a texture analyzer (Model TA1000, Stevens LFRA, Harlow, UK). A solution containing $6.67 \%(w / v)$ gelatin sample was prepared by mixing $7.5 \mathrm{~g}$ of gelatin and $105 \mathrm{~mL}$ of $\mathrm{ddH}_{2} \mathrm{O}$ in a Bloom bottle. The mixture was stirred and allowed to stand for $30 \mathrm{~min}$ at room temperature to allow the gelatin to absorb water and swell. The Bloom bottles were transferred to a water bath and maintained at $42{ }^{\circ} \mathrm{C}$ for $30 \mathrm{~min}$ with intermittent stirring. The samples were then transferred to a cold water bath, which was maintained at $10 \pm 0.1{ }^{\circ} \mathrm{C}$. The samples were kept at this temperature for 16-18 h before evaluating the gel strength. The 
Bloom gel strength (in g) was assessed with the texture analyzer set to generate a $4 \mathrm{~mm}$ depression at a rate of $0.5 \mathrm{~mm} / \mathrm{s}$.

\subsection{Differential Scanning Calorimetry (DSC)}

A sample of lyophilized protein weighing $5 \mathrm{mg}$ was accurately weighed and placed on an aluminum pan, hermetically sealed, and then scanned from 0 to $200^{\circ} \mathrm{C}$ at a heating rate of $5^{\circ} \mathrm{C} / \mathrm{min}$. An empty sealed aluminum pan served as a reference. Software was used to record the maximum denaturation temperature $\left(T_{\max }\right)$, which was deemed to be the peak temperature of each endothermic peak. The total denaturation enthalpy $(\Delta \mathrm{H})(\mathrm{J} / \mathrm{g}$ protein sample) was assessed for each peak by calculating the corresponding area under each of the endothermic peaks. The analysis was conducted using a DSC 200 F3 calorimeter (Netzsch-Gerätebau GmbH, Selb, Germany), which was calibrated for temperature and enthalpy with indium as the standard. The measurements were performed while samples were being continuously purged using ultra-high-purity nitrogen at $50 \mathrm{~cm}^{3} / \mathrm{min}$ [18].

\subsection{Determination of Viscosity}

The analysis was based on a previous report [51] with some modification. In brief, each of the gelatin samples $(6.67 \%, w / v)$ was placed in a water bath maintained at $45{ }^{\circ} \mathrm{C}$ until it had melted. The viscosity was recorded at $60^{\circ} \mathrm{C}$ using a DV-II + PRO viscometer (Brookfield, MA, USA). The measurements were carried out in triplicate.

\subsection{Sensory Evaluation}

The sensory evaluation was performed using a 24-member panel. Individuals capable of detecting off-odor in samples with a slightly putrid odor were selected for this evaluation. Samples used for the sensory evaluation were prepared using lyophilized gelatin powder. The samples (in solution $6.67 \% ; w / v$ or in powder) were placed in test tubes with screw caps. The samples in solution were kept in a water bath at $50{ }^{\circ} \mathrm{C}$ with the screw caps lightly tightened. In each assessment, panelists were instructed to remove the screw caps and then smell the contents. They were then required to identify the odor that they perceived and record the odor acceptability. A nine-point hedonic scale ( 1 = very bad; $5=$ moderate; 9 = very good) was employed for the evaluation of odor acceptability.

\subsection{Fourier Transform Infrared (FTIR) Spectroscopy}

A volume of protein powder measuring $2 \mathrm{mg}$ was evenly ground with approximately $100 \mathrm{mg} \mathrm{KBr}$ until the particles measured less than $2.5 \mu \mathrm{m}$ in size. The transparent $\mathrm{KBr}$ pieces were generated at $500 \mathrm{~kg} / \mathrm{cm}^{2}$ under vacuum condition. An FT-730 spectrometer (Horiba, Kyoto, Japan) was used to obtain the FTIR spectra. The signals were collected automatically using 60 scans covering the range $4000-400 \mathrm{~cm}^{-1}$ at a resolution of $2 \mathrm{~cm}^{-1}$ and were compared to a background spectrum collected using $\mathrm{KBr}$ alone.

\subsection{Preparation of Gelatin Hydrolysates}

Two proteases, pepsin and pancreatin, were used for the digestion of gelatin. For the digestion of gelatin using pepsin, gelatin $(4.5 \mathrm{~g})$ was dissolved in a $150 \mathrm{~mL} 0.1 \mathrm{M} \mathrm{KCl}-\mathrm{HCl}$ buffer solution $(\mathrm{pH}=2.0)$, and then hydrolyzed with pepsin (protein to pepsin ratio was $25: 1(w / w))$ for $4 \mathrm{~h}$ at $37^{\circ} \mathrm{C}$ in a batch reactor. The $\mathrm{pH}$ was adjusted to 7.0 by $2 \mathrm{~N} \mathrm{NaOH}$, and then the resulting solution was heated at $98^{\circ} \mathrm{C}$ for $10 \mathrm{~min}$ in order to inactivate the protease. For the digestion of gelatin using pepsin + pancreatin, the gelatin ( $4.5 \mathrm{~g})$ was dissolved in a $150 \mathrm{~mL} 0.1 \mathrm{M} \mathrm{KCl}-\mathrm{HCl}$ buffer solution ( $\mathrm{pH}=2.0$ ), and hydrolyzed with pepsin (the protein to pepsin ratio was $25: 1(w / w))$ for $4 \mathrm{~h}$ at $37^{\circ} \mathrm{C}$ in a batch reactor. The $\mathrm{pH}$ was adjusted to 7.0 by $2 \mathrm{~N} \mathrm{NOH}$, and further hydrolyzed using pancreatin (the protein to pancreatin ratio was $25: 1(w / w))$ for $4 \mathrm{~h}$ at $37^{\circ} \mathrm{C}$ in a batch reactor. The resulting solution was heated at $98^{\circ} \mathrm{C}$ for $10 \mathrm{~min}$ in order to inactivate the protease. The abovementioned gelatin hydrolysates were cooled using cold flowing water, and then separated using an ultrafiltration membrane with a molecular weight cut-off (MWCO) of 3000 Da. Both the retentate and permeate 
fractions were subsequently collected and lyophilized. A summary of the operational variables for enzymatic digestion of TSG2, and four gelatin hydrolysates, namely TSGH1 (digested by pepsin and MWCO > 3000 Da), TSGH2 (digested by pepsin + pancreatin and MWCO > $3000 \mathrm{Da}$ ), TSGH3 (digested by pepsin and MWCO < $3000 \mathrm{Da}$ ), and TSGH4 (digested by pepsin + pancreatin and $\mathrm{MWCO}<3000 \mathrm{Da}$ ) can be viewed in Table 3 .

\subsection{Molecular Weight Analysis}

With respect to the molecular analysis of the gelatin samples, a size exclusion HPLC column Superdex 200 (300 mm × 10 mm ID) (GE Healthcare Life Sciences, Chicago, IL, USA) was used, which utilized a Shimadzu HPLC system (Shimadzu, Kyoto, Japan). The conditions of chromatography were as follows: eluent $0.02 \mathrm{M}$ sodium phosphate and $0.25 \mathrm{M}$ sodium chloride, at $\mathrm{pH} 7.2$; flow rate $0.4 \mathrm{~mL} / \mathrm{min}$, sample concentration $1 \%$; injection volume $100 \mu \mathrm{L}$; temperature $25^{\circ} \mathrm{C}$; and wavelength $280 \mathrm{~nm}$. The standard proteins used to calibrate MW were apoferritin (443 kDa), myosin (200 kDa), BSA (66 kDa), and pepsin $(35 \mathrm{kDa})$. The molecular analysis of gelatin hydrolysate was performed using a size exclusion HPLC column Superdex Peptide HR 10/30 column $(300 \mathrm{~mm} \times 10 \mathrm{~mm}$ ID) (GE Healthcare Life Sciences, Chicago, IL, USA) with a Shimadzu HPLC system (Shimadzu, Kyoto, Japan). The conditions of chromatography were as follows: eluent $0.02 \mathrm{M}$ sodium phosphate and $0.25 \mathrm{M}$ sodium chloride, at $\mathrm{pH} 7.2$; flow rate $0.5 \mathrm{~mL} / \mathrm{min}$, sample concentration $1 \%$; injection volume $50 \mu \mathrm{L}$; temperature $25^{\circ} \mathrm{C}$; and wavelength $214 \mathrm{~nm}$. The standard proteins used for calibration of MW were BSA (66 kDa), trypsin inhibitor $(20 \mathrm{kDa})$, aprotinin (6511 Da), glutathione (307 Da), gly-gly-gly (189 Da), and glycine $(75 \mathrm{Da})$.

\subsection{Two-Step Separation of Gelatin Hydrolysates by Reversed-Phase High-Performance Liquid Chromatography (RP-HPLC)}

A Shimadzu HPLC system (Shimadzu, Kyoto, Japan) equipped with an Inspire C18 column $(250 \times 4.6 \mathrm{~mm}, 5 \mu \mathrm{m})$ was utilized to separate gelatin hydrolysates. In the first-step of the separation process, the mobile phase was 30\% acetonitrile (ACN) $/ 0.1 \%$ trifluoroacetic acid (TFA). A volume of gelatin hydrolysates measuring $50 \mu \mathrm{L}$ was injected into the column and eluted with the mobile phase at a flow rate of $1 \mathrm{~mL} / \mathrm{min}$. The separation was monitored at a wavelength of $214 \mathrm{~nm}$ and the fractions were collected every minute and used for additional experiments. In the second-step separation, solvent A was $0.05 \% \mathrm{TFA}$ and solvent B was 100\% ACN. A volume of peptides measuring $100 \mu \mathrm{L}$ was eluted using a linear gradient from $0 \%$ to $50 \%$ of solvent $B$ for $5 \mathrm{~min}$ at a flow rate of $1 \mathrm{~mL} / \mathrm{min}$. The separation was monitored at a wavelength of $214 \mathrm{~nm}$ and the fractions were collected every minute for additional experiments.

\subsection{DPPH Radical Scavenging Activity}

The DPPH radical scavenging activity was assessed using a protocol described elsewhere [52]. A volume measuring $50 \mu \mathrm{L}$ was added to $200 \mu \mathrm{L} 0.1 \mathrm{mM}$ DPPH solution (in methanol). The mixture was then vortexed for $1 \mathrm{~min}$ and left in the dark for $30 \mathrm{~min}$ at room temperature. Next, the absorbance of the solutions was measured at $517 \mathrm{~nm}$ using a PowerWave 340 ELISA reader (Bio-Tek Instruments, Winooski, VT, USA). Equation (3) was used to assess the scavenging activity of the DPPH radicals:

$$
\text { Scavenging activity }(\%)=\left(1-\mathrm{A}_{\text {sample }} / \mathrm{A}_{\text {control }}\right) \times 100
$$

where $A_{\text {control }}$ represents the absorbance of the methanol solution of DPPH without the sample and $\mathrm{A}_{\text {sample }}$ denotes the absorbance of the methanol solution of DPPH with the tested samples.

\subsection{ABTS Radical Scavenging Activity}

The ABTS radical scavenging activity was evaluated according to method described elsewhere [53]. The ABTS reagent was generated by mixing $5 \mathrm{~mL}$ of $7 \mathrm{mM}$ ABTS solution 
with $88 \mu \mathrm{L}$ of $140 \mathrm{mM}$ potassium persulfate in the dark at room temperature for $16 \mathrm{~h}$ in order to complete the formation of radicals. The solution was then diluted with $95 \%$ ethanol such that the absorbance at $734 \mathrm{~nm}$ fell within the range $0.70 \pm 0.05$. To analyze the scavenging activity, $100 \mu \mathrm{L}$ ABTS reagent was mixed with $100 \mu \mathrm{L}$ of each sample solution. The mixture was reacted at room temperature for $6 \mathrm{~min}$ and the absorbance was read at $734 \mathrm{~nm}$ using a PowerWave 340 ELISA reader (Bio-Tek Instruments). The blank was prepared according to the same protocol using distilled water rather than the sample. Equation (4) was used to calculate the scavenging activity of ABTS radicals:

$$
\text { Scavenging activity }(\%)=\left(1-\mathrm{A}_{\text {sample }} / \mathrm{A}_{\text {control }}\right) \times 100
$$

where $\mathrm{A}_{\text {control }}$ denotes the absorbance of ABTS without the sample and $\mathrm{A}_{\text {sample }}$ represents the absorbance of ABTS with the tested samples. Trolox was prepared as a standard. A calibration curve showing the scavenging percentage against the various concentrations of Trolox standard was created. The ABTS radical scavenging activity of the samples was expressed as Trolox equivalent antioxidant capacity (TEAC), indicating the concentration $(\mu \mathrm{M})$ of Trolox.

\subsection{Reducing Power Assay}

The reducing power was evaluated according to a previously described protocol [54]. In brief, $0.5 \mathrm{~mL}$ of the sample was mixed with $0.5 \mathrm{~mL}$ of phosphate buffer $(0.2 \mathrm{M}, \mathrm{pH}$ 6.6) and $0.5 \mathrm{~mL}$ of potassium ferricyanide $(1 \%)$. The mixture was then incubated at $50{ }^{\circ} \mathrm{C}$ for $20 \mathrm{~min}$, followed by addition of $0.5 \mathrm{~mL}$ of trichloroacetic acid (10\%) and centrifugation (970 $\times g$ for $10 \mathrm{~min})$. Finally, $0.5 \mathrm{~mL}$ of the supernatant solution was mixed with $0.5 \mathrm{~mL}$ of $\mathrm{ddH}_{2} \mathrm{O}$ and $0.1 \mathrm{~mL}$ of $\mathrm{FeCl}_{3}(0.1 \%)$, and allowed to stand for $10 \mathrm{~min}$. The absorbance was measured at $700 \mathrm{~nm}$ using a PowerWave 340 ELISA reader (Bio-Tek Instruments). Increased absorbance of the reaction mixture indicated increased reducing power.

\subsection{LC-ESI/MS/MS and Data Analyses}

An UltiMate 3000 RSLCnano LC Systems (Thermo Fisher Scientific, San Jose, CA, USA) connected to a TripleTOF ${ }^{\circledR} 6600$ System (Applied Biosystems Sciex, Framingham, MA, USA) equipped with a nanoelectrospray ion source was used. The peptides, which had been dissolved in $\mathrm{ddH}_{2} \mathrm{O}$, were desalted in a C18 trap column $(100 \mu \mathrm{m} \times 2 \mathrm{~cm}$ nanoViper, $3 \mu \mathrm{m}, 100 \AA$, Thermo Fisher Scientific) for $4.5 \mathrm{~min}$ at a flow rate of $10 \mu \mathrm{L} / \mathrm{min}$. Samples were subsequently dried and redissolved in $\mathrm{ddH}_{2} \mathrm{O}$ containing $0.1 \%$ FA. Aliquots $(10 \mu \mathrm{L})$ were then injected using an autosampler. Next, the sample was separated using a C18 resolving column (75 $\mu \mathrm{m}$ I.D. $\times 25 \mathrm{~cm}$ nanoViper, $2 \mu \mathrm{m}, 100 \AA$, Thermo Fisher Scientific) at a flow rate of $300 \mathrm{~nL} / \mathrm{min}$. The mobile phases were composed of water with $0.1 \%$ formic acid (A) and 100\% acetonitrile with $0.1 \%$ formic acid (B), respectively. The peptides were separated using a linear gradient of $5 \%$ to $30 \%$ B over $90 \mathrm{~min}$, followed by $30 \%$ to $60 \%$ for $6 \mathrm{~min}$, and $60 \%$ to $90 \%$ for an additional $6 \mathrm{~min}$. The mass spectrometer readings were done using the information-dependent acquisition (IDA) mode, which the initial MS scan analyzes the mass to charge $(\mathrm{m} / \mathrm{z})$ ratios of ions in the mass range 350-1500 Da. The 20 most abundant ions were automatically selected for collision-activated dissociation. All of the MS/MS data were searched against the UniProtKB/Swiss-Prot database using the Mascot program (Matrix Science Ltd. London, UK, version 2.4).

\subsection{Statistical Analysis}

The experiments were conducted at least three times, and all of the data are presented as mean \pm standard deviation (SD). Statistical analyses were done using the Statistical Package for the Social Sciences (SPSS). The statistical analyses were one-way analysis of variance (ANOVA), followed by Duncan's Multiple Range tests. A difference was considered statistically significant when $p<0.05$. 


\section{Conclusions}

In the present study, we found that an extrusion-pretreatment process increased the extraction yield of gelatin from tilapia scale samples. Moreover, TSG2 (preconditioning with $1.26 \%$ citric acid) possessed the highest extraction yield, high gelatin purity, a relatively high whiteness index, high bloom gel strength, high viscosity, high odor acceptability, high thermal stability, and high antioxidant activities, indicating the preconditioning of citric acid before extrusion is beneficial in promoting the quality of gelatin. Among the four gelatin hydrolysates generated from TSG2, TSGH4 (digested by pepsin + pancreatin and MWCO $<3000 \mathrm{Da}$ ) had a higher yield and exhibited superior antioxidant activities. TSGH4 were further fractionated by Superdex peptide and 2-step RP-HPLC chromatography, which yielded the subfraction containing the most antioxidants, TSGH4-6-2-b. LC-ESI/MS/MS analysis of TSGH4-6-2-b revealed that two peptide sequences (GYDEY and EPGKSGEQGAPGEAGAP) may have potential as novel antioxidant peptides. Our findings provide a method of reusing fish by-product waste, which might be of value in the fishery industries. Further in-depth exploration of these two novel antioxidant peptides, including in vivo studies, is needed.

Supplementary Materials: The following are available online at https:/ /www.mdpi.com/article/ 10.3390/md19050275/s1, Figure S1: Size exclusion chromatographic profiles for TSGH1, TSGH2, TSGH3, and TSGH4. Trypsin, aprotinin, glutathione, Gly-Gly-Gly, and glycine were utilized as the standard proteins.

Author Contributions: Conceptualization, W.-C.S. and T.-C.W.; methodology, Y.-H.T.; software, W.-C.S.; validation, M.-L.T., Y.-H.H., and C.-Y.H.; formal analysis, W.-C.S., M.-L.T., and Y.-H.H.; investigation, Y.-H.T., C.-H.K., and Y.-H.H.; resources, T.-C.W., C.-H.K., and W.-C.S.; data curation, M.L.T. and T.-C.W.; writing—original draft preparation, T.-C.W., Y.-H.H., and C.-H.K.; writing-review and editing, T.-C.W., W.-C.S., and C.-Y.H.; supervision, Y.-H.H. and C.-Y.H.; project administration, C.-Y.H.; funding acquisition, T.-C.W., W.-C.S., Y.-H.H., and C.-Y.H. All authors have read and agreed to the published version of the manuscript.

Funding: This research was funded by Yuan's General Hospital, Taiwan, grant number YUANIACR-21-01 to Wei-Cheng Shiao. This research was funded by a grant provided by the Kaohsiung Medical University Hospital (KMUH109-M906) to Tien-Chiu Wu. This work was also supported by the Ministry of Science and Technology, Taiwan (grant number MOST 109-2221-E-992-052) and National Kaohsiung University of Science and Technology, Taiwan (grant number 110G07), which were awarded to Chun-Yung Huang. The authors thank the Ministry of Education, Taiwan, for supporting this study (grant number MOE-RSC-108RSN0005), awarded to Yong-Han Hong.

Institutional Review Board Statement: Not applicable.

Data Availability Statement: Data are contained within the article.

Conflicts of Interest: The authors declare no conflict of interest.

\section{References}

1. Thakur, K.; Zhang, Y.Y.; Mocan, A.; Zhang, F.; Zhang, J.G.; Wei, Z.J. 1-Deoxynojirimycin, its potential for management of non-communicable metabolic diseases. Trends Food Sci. Technol. 2019, 89, 88-99. [CrossRef]

2. Wang, J.; Liao, A.M.; Thakur, K.; Zhang, J.G.; Huang, J.H.; Wei, Z.J. Licochalcone B extracted from Glycyrrhiza uralensis fisch induces apoptotic effects in human hepatoma cell HepG2. J. Agric. Food Chem. 2019, 67, 3341-3353. [CrossRef] [PubMed]

3. Castro, L.; Freeman, B.A. Reactive oxygen species in human health and disease. Nutrition 2001, 17, 161-165. [CrossRef]

4. Aruoma, O.I. Free radicals, oxidative stress, and antioxidants in human health and disease. J. Am. Oil Chem. Soc. 1998, 75, 199-212. [CrossRef] [PubMed]

5. Ito, N.; Fukushima, S.; Haqlwara, A.; Shibata, M.; Ogiso, T. Carcinogenicity of butylated hydroxyanisole in F344 rats. J. Natl. Cancer Inst. 1983, 70, 343-352.

6. Huang, C.Y.; Kuo, C.H.; Lee, C.H. Antibacterial and antioxidant capacities and attenuation of lipid accumulation in 3T3-L1 adipocytes by low-molecular-weight fucoidans prepared from compressional-puffing-pretreated Sargassum crassifolium. Mar. Drugs 2018, 16, 24. [CrossRef] 
7. Yang, W.N.; Chen, P.W.; Huang, C.Y. Compositional characteristics and in vitro evaluations of antioxidant and neuroprotective properties of crude extracts of fucoidan prepared from compressional puffing-pretreated Sargassum crassifolium. Mar. Drugs 2017, 15, 183. [CrossRef]

8. Huang, C.Y.; Tsai, Y.H.; Hong, Y.H.; Hsieh, S.L.; Huang, R.H. Characterization and antioxidant and angiotensin I-converting enzyme (ACE)-inhibitory activities of gelatin hydrolysates prepared from extrusion-pretreated milkfish (Chanos chanos) scale. Mar. Drugs 2018, 16, 346. [CrossRef]

9. Huang, C.Y.; Kuo, C.H.; Wu, C.H.; Kuan, A.W.; Guo, H.R.; Lin, Y.H.; Wang, P.K. Free radical-scavenging, anti-inflammatory, and antibacterial activities of water and ethanol extracts prepared from compressional-puffing pretreated mango (Mangifera indica L.) peels. J. Food Qual. 2018, 2018, 1025387. [CrossRef]

10. Zhao, X.; Zhou, Y.; Zhao, L.; Chen, L.; He, Y.; Yang, H. Vacuum impregnation of fish gelatin combined with grape seed extract inhibits protein oxidation and degradation of chilled tilapia fillets. Food Chem. 2019, 294, 316-325. [CrossRef]

11. Liu, D.; Nikoo, M.; Boran, G.; Zhou, P.; Regenstein, J.M. Collagen and gelatin. Annu. Rev. Food Sci. Technol. 2015, 6, 527-557. [CrossRef] [PubMed]

12. Al-Nimry, S.; Dayah, A.A.; Hasan, I.; Daghmash, R. Cosmetic, biomedical and pharmaceutical applications of fish gelatin/hydrolysates. Mar. Drugs 2021, 19, 145. [CrossRef]

13. Chen, K.; Yang, X.; Huang, Z.; Jia, S.; Zhang, Y.; Shi, J.; Hong, H.; Feng, L.; Luo, Y. Modification of gelatin hydrolysates from grass carp (Ctenopharyngodon idellus) scales by Maillard reaction: Antioxidant activity and volatile compounds. Food Chem. 2019, 295, 569-578. [CrossRef]

14. Kim, S.K.; Kim, Y.T.; Byun, H.G.; Nam, K.S.; Joo, D.S.; Shahidi, F. Isolation and characterization of antioxidative peptides from gelatin hydrolysate of Alaska pollack skin. J. Agric. Food Chem. 2001, 49, 1984-1989. [CrossRef] [PubMed]

15. Camire, M.E.; Camire, A.; Krumhar, K. Chemical and nutritional changes in foods during extrusion. Crit. Rev. Food Sci. Nutr. 1990, 29, 35-57. [CrossRef] [PubMed]

16. Chen, W.H.; Xu, Y.Y.; Hwang, W.S.; Wang, J.B. Pretreatment of rice straw using an extrusion/extraction process at bench-scale for producing cellulosic ethanol. Bioresour. Technol. 2011, 102, 10451-10458. [CrossRef] [PubMed]

17. Jing, Y.; Chi, Y.J. Effects of twin-screw extrusion on soluble dietary fibre and physicochemical properties of soybean residue. Food Chem. 2013, 138, 884-889. [CrossRef] [PubMed]

18. Huang, C.Y.; Kuo, J.M.; Wu, S.J.; Tsai, H.T. Isolation and characterization of fish scale collagen from tilapia (Oreochromis sp.) by a novel extrusion-hydro-extraction process. Food Chem. 2016, 190, 997-1006. [CrossRef]

19. Fisheries Agency, Council of Agriculture, Executive Yuan, Taiwan. Fisheries Statistical Yearbook. 2019. Available online: https:/ / www.fa.gov.tw/cht/PublicationsFishYear/ (accessed on 21 April 2021).

20. Ikoma, T.; Kobayashi, H.; Tanaka, J.; Walsh, D.; Mann, S. Physical properties of type I collagen extracted from fish scales of Pagrus major and Oreochromis niloticas. Int. J. Biol. Macromol. 2003, 32, 199-204. [CrossRef]

21. Muyonga, J.H.; Cole, C.G.B.; Duodu, K.G. Extraction and physico-chemical characterisation of Nile perch (Lates niloticus) skin and bone gelatin. Food Hydrocoll. 2004, 18, 581-592. [CrossRef]

22. Arnesen, J.A.; Gildberg, A. Extraction and characterisation of gelatine from Atlantic salmon (Salmo salar) skin. Bioresour. Technol. 2007, 98, 53-57. [CrossRef]

23. Jongjareonrak, A.; Rawdkuen, S.; Chaijan, M.; Benjakul, S.; Osako, K.; Tanaka, M. Chemical compositions and characterisation of skin gelatin from farmed giant catfish (Pangasianodon gigas). LWT Food Sci. Technol. 2010, 43, 161-165. [CrossRef]

24. Jongjareonrak, A.; Benjakul, S.; Visessanguan, W.; Tanaka, M. Skin gelatin from bigeye snapper and brownstripe red snapper: Chemical compositions and effect of microbial transglutaminase on gel properties. Food Hydrocoll. 2006, 20, 1216-1222. [CrossRef]

25. Cheow, C.S.; Norizah, M.S.; Kyaw, Z.Y.; Howell, N.K. Preparation and characterisation of gelatins from the skins of sin croaker (Johnius dussumieri) and shortfin scad (Decapterus macrosoma). Food Chem. 2007, 101, 386-391. [CrossRef]

26. Sperling, L.H. Introduction to Physical Polymer Science; Wiley: New York, NY, USA, 1985.

27. Johnston-Banks, F.A. Gelatine. In Food Gels; Harris, P., Ed.; Elsevier Applied Science: London, UK, 1990; pp. $233-285$.

28. Wangtueai, S.; Noomhorm, A. Processing optimization and characterization of gelatin from lizardfish (Saurida spp.) scales. LWT Food Sci. Technol. 2009, 42, 825-834. [CrossRef]

29. Liu, D.; Liang, L.; Regenstein, J.M.; Zhou, P. Extraction and characterisation of pepsin-solubilised collagen from fins, scales, skins, bones and swim bladders of bighead carp (Hypophthalmichthys nobilis). Food Chem. 2012, 133, 1441-1448. [CrossRef]

30. Safandowska, M.; Pietrucha, K. Effect of fish collagen modification on its thermal and rheological properties. Int. J. Biol. Macromol. 2013, 53, 32-37. [CrossRef]

31. Kittiphattanabawon, P.; Benjakul, S.; Visessanguan, W.; Shahidi, F. Comparative study on characteristics of gelatin from the skins of brownbanded bamboo shark and blacktip shark as affected by extraction conditions. Food Hydrocoll. 2010, $24,164-171$. [CrossRef]

32. Muyonga, J.H.; Cole, C.G.B.; Duodu, K.G. Characterisation of acid soluble collagen from skins of young and adult Nile perch (Lates niloticus). Food Chem. 2004, 85, 81-89. [CrossRef]

33. Muyonga, J.H.; Cole, C.G.B.; Duodu, K. Fourier transform infrared (FTIR) spectroscopic study of acid soluble collagen and gelatin from skins and bones of young and adult Nile perch (Lates niloticus). Food Chem. 2004, 86, 325-332. [CrossRef] 
34. Martins, M.E.O.; Sousa, J.R.; Claudino, R.L.; Lino, S.C.O.; Vale, D.A.D.; Silva, A.L.C.; Morais, J.P.S.; De Souza Filho, M.d.S.M.; De Souza, B.W. Thermal and chemical properties of gelatin from tilapia (Oreochromis niloticus) scale. J. Aquat. Food Prod. Technol. 2018, 27, 1120-1133. [CrossRef]

35. Rokesh, K.; Nithya, A.; Jeganathan, K.; Jothivenkatachalam, K. A facile solid state synthesis of cone-like ZnO microstructure an efficient solar-light driven photocatalyst for rhodamine B degradation. Mater. Today Proc. 2016, 3, 4163-4172. [CrossRef]

36. Cai, L.; Wu, X.; Zhang, Y.; Li, X.; Ma, S.; Li, J. Purification and characterization of three antioxidant peptides from protein hydrolysate of grass carp (Ctenopharyngodon idella) skin. J. Funct. Foods 2015, 16, 234-242. [CrossRef]

37. Leong, L.P.; Shui, G. An investigation of antioxidant capacity of fruits in Singapore markets. Food Chem. 2002, 76, 69-75. [CrossRef]

38. Senevirathne, M.; Kim, S.H.; Siriwardhana, N.; Ha, J.H.; Lee, K.W.; Jeon, Y.J. Antioxidant potential of Ecklonia cavaon reactive oxygen species scavenging, metal chelating, reducing power and lipid peroxidation inhibition. Food Sci. Technol. Int. 2006, 12, 27-38. [CrossRef]

39. Korhonen, H.; Pihlanto, A. Food-derived bioactive peptides-opportunities for designing future foods. Curr. Pharm. Des. 2003, 9, 1297-1308. [CrossRef] [PubMed]

40. Wang, J.; Zhang, Q.; Zhang, Z.; Song, H.; Li, P. Potential antioxidant and anticoagulant capacity of low molecular weight fucoidan fractions extracted from Laminaria japonica. Int. J. Biol. Macromol. 2010, 46, 6-12. [CrossRef] [PubMed]

41. Lemieux, L.; Piot, J.M.; Guillochon, D.; Amiot, J. Study of the efficiency of a mobile phase used in size-exclusion HPLC for the separation of peptides from a casein hydrolysate according to their hydrodynamic volume. Chromatographia 1991, 32, 499-504. [CrossRef]

42. Li, Z.; Wang, B.; Chi, C.; Gong, Y.; Luo, H.; Ding, G. Influence of average molecular weight on antioxidant and functional properties of cartilage collagen hydrolysates from Sphyrna lewini, Dasyatis akjei and Raja porosa. Food Res. Int. 2013, 51, 283-293. [CrossRef]

43. Dávalos, A.; Miguel, M.; Bartolome, B.; Lopez-Fandino, R. Antioxidant activity of peptides derived from egg white proteins by enzymatic hydrolysis. J. Food Prot. 2004, 67, 1939-1944. [CrossRef]

44. Hsu, K.C. Purification of antioxidative peptides prepared from enzymatic hydrolysates of tuna dark muscle by-product. Food Chem. 2010, 122, 42-48. [CrossRef]

45. Girgih, A.T.; He, R.; Malomo, S.; Offengenden, M.; Wu, J.; Aluko, R.E. Structural and functional characterization of hemp seed (Cannabis sativa L.) protein-derived antioxidant and antihypertensive peptides. J. Funct. Foods 2014, 6, 384-394. [CrossRef]

46. De Gobba, C.; Espejo-Carpio, F.J.; Skibsted, L.H.; Otte, J. Antioxidant peptides from goat milk protein fractions hydrolysed by two commercial proteases. Int. Dairy J. 2014, 39, 28-40. [CrossRef]

47. Nagai, T.; Suzuki, N. Isolation of collagen from fish waste material-Skin, bone and fins. Food Chem. 2000, 68, 277-281. [CrossRef]

48. Lowry, O.H.; Rosebrough, N.J.; Farr, A.L.; Randall, R.J. Protein measurement with the Folin phenol reagent. J. Biol. Chem. 1951, 193, 265-275. [CrossRef]

49. AOAC. Methods of Analysis, 14th ed.; Association of Official Analytical Chemists: Washington, DC, USA, 1984.

50. BSI. Methods for Sampling and Testing Gelatin (Physical and Chemical Methods); BSI (British Standards Institution): London, UK, 1975.

51. Songchotikunpan, P.; Tattiyakul, J.; Supaphol, P. Extraction and electrospinning of gelatin from fish skin. Int. J. Biol. Macromol. 2008, 42, 247-255. [CrossRef]

52. Huang, C.Y.; Kuo, C.H.; Chen, P.W. Compressional-puffing pretreatment enhances neuroprotective effects of fucoidans from the brown seaweed Sargassum hemiphyllum on 6-hydroxydopamine-induced apoptosis in SH-SY5Y cells. Molecules 2018, 23, 78. [CrossRef]

53. Huang, C.Y.; Wu, S.J.; Yang, W.N.; Kuan, A.W.; Chen, C.Y. Antioxidant activities of crude extracts of fucoidan extracted from Sargassum glaucescens by a compressional-puffing-hydrothermal extraction process. Food Chem. 2016, 197, 1121-1129. [CrossRef]

54. Wang, C.Y.; Wu, T.C.; Hsieh, S.L.; Tsai, Y.H.; Yeh, C.W.; Huang, C.Y. Antioxidant activity and growth inhibition of human colon cancer cells by crude and purified fucoidan preparations extracted from Sargassum cristaefolium. J. Food Drug Anal. 2015, 23, 766-777. [CrossRef] 